\title{
33. MIDDLE EOCENE BENTHIC FORAMINIFERS FROM HOLES 960A AND 960C, CENTRAL ATLANTIC OCEAN ${ }^{1}$
}

\author{
Gérard Bignot ${ }^{2}$
}

\begin{abstract}
Benthic foraminifers of Eocene age from Holes $960 \mathrm{~A}$ and $960 \mathrm{C}$ of the Ocean Drilling Program Leg 159 were examined. More than 70 species were isolated and identified. Very few fossiliferous samples are scattered in a sequence, which for the most part, is barren of calcareous microfossils. Based on the biostratigraphic analysis of their benthic foraminifer content, these fossiliferous samples are given a Bartonian age.

Despite some important intervals without any recovery, it appears that a long episode of strong carbonate dissolution was interrupted during Bartonian times by one or more sporadic and brief events of slight corrosion. We suggest that the samples were deposited in middle-lower bathyal environments at about $2 \pm 1 \mathrm{~km}$ water depth, close to the lower limit of an oxygen minimum zone.
\end{abstract}

\section{INTRODUCTION AND GEOGRAPHICAL SETTING}

We examined benthic foraminifers from nine samples of Eocene age from Ocean Drilling Program Holes 960A and 960C, located on the top of the Marginal Ivorian Ridge (Fig. 1).

The analyzed samples were taken in a poorly recovered Paleogene sequence, truncated by an erosional event during the late Eocene and the Oligocene. According to the preliminary shipboard studies (Shipboard Scientific Party, 1996), the major part of the Paleogene section appears to be barren of calcareous microfossils and is dated Paleocene-Eocene by using sporadic and poorly preserved nannofossils (CP10 and $\mathrm{CP} 12 \mathrm{a}-13)$ and planktonic foraminifers (P3/6 and P1011).

\section{MATERIALS AND METHODS}

After drying, 10 to $20 \mathrm{~cm}^{3}$ of each sample were disaggregated in paraffin oil for $24 \mathrm{hr}$ and then washed using a thin trickle of water on nested sieves of $125-\mu \mathrm{m}$ average mesh size.

This method permitted us to preserve the most delicate ornamental features of various microfossils, especially radiolarians.

Benthic foraminifers and other microfossils were identified (Fig. 2 ) and counted from the $125-\mu \mathrm{m}$ size fraction. Percentages of planktonic foraminifers were also estimated (Fig. 3).

\section{CHARACTERISTICS AND PRESERVATION OF THE ASSEMBLAGES}

Samples 159-960A-14R-1, 39-42 cm, and 159-960C-17X-1, $112-114 \mathrm{~cm}$, yielded a rich and well-diversified assemblage of benthic foraminifers.

More than 70 species were separated from the two samples (Fig. 2). Dominant taxa are represented by two genera: Stilostomella (Pl. 2, Figs. 10-13, and Pl. 3, Figs. 12-15) and Bulimina (Pl. 2, Figs. 16 ) and by two species: Globocassidulina subglobosa (Pl. 4, Figs. 17,

${ }^{1}$ Mascle, J., Lohmann, G.P., and Moullade, M. (Eds.), 1998. Proc. ODP, Sci. Results, 159: College Station, TX (Ocean Drilling Program).

${ }^{2}$ Laboratoire de Micropaléontologie, Département de Géologie Sédimentaire, Université Pierre et Marie Curie, Place Jussieu, T 15, E 4, C 104, 75252 Paris Cedex 5, France.
18) and Oridorsalis umbonatus. On the other hand, many species are represented by only one or a few specimens per sample.

We identified all microfossils, but because of their eventual scarcity and poor preservation, some of them have been left in open nomenclature. Two species appear to be new and one is described (Pyramidina africana n. sp., Pl. 3, Figs. 1-11).

In these two samples, benthic foraminifers are associated with planktonic foraminifers, numerous radiolarians, small echinid reticulated spines, and some ichthyoliths.

Other Eocene samples also contain ichthyoliths, siliceous sponge spicules, and sometimes numerous radiolarians (Samples 159-960A15R-1, 114-116 cm, and 159-960C-15H-4, 113-115 cm), but foraminifers are absent or very scarce (one or few specimens per sample). All identified microfossils are listed in Figure 3.

The preservation of Samples 159-960A-14R-1, 39-42 cm, and $159-960 \mathrm{C}-17 \mathrm{X}-1,112-114 \mathrm{~cm}$, varies according to the species.

Benthic foraminifers show the following features: loss of surface smoothness (e.g., Nodosariidae), thinning of wall and fragility of test, etching of ornamentation (e.g., costae, Rectuvigerina mexicana; Pl. 2, Fig. 16), apertural details (Chrysalogonium; Pl. 1, Fig. 10), widening of pores (Cibicidoides grimsdalei; Pl. 4, Figs. 3, 4), breakage of rectilinear tests (Chrysalogonium; Pl. 1, Figs, 9-11, 13; Stilostomella; Pl. 2, Figs. 10-13, and Pl. 3, Figs. 12, 13) or of the last chamber(s) of coiled tests (Cibicidoides grimsdalei; Pl. 4, Figs. 3, 4), calcite overgrowths upon the test surface (sugary appearance) obscuring fine details (Caucasina? n? sp.; Pl. 4, Fig. 14), complete recrystallization, and pulverization of Miliolids tests.

Planktonic foraminifers are more etched than the benthic ones, and representatives of Clavigerinella are sometimes reduced to isolated chambers after the complete disappearance of the umbilical portion of the test (Pl. 4, Figs. 19, 20). Probably some (or numerous?) specimens were entirely dissolved. Thus, it is difficult to establish an accurate planktonic/benthic ratio. In Sample 159-960C-17X-1, 112$114 \mathrm{~cm}$, this apparent ratio is about $35 \%$. Benthic species dominance is proposed in Figure 3.

\section{BIOSTRATIGRAPHIC REMARKS}

Numerous species of Eocene benthic foraminifers present in Holes 960A and 960C have little stratigraphic significance. However, some of them have shorter ranges and are considered as good index fossils. Several taxa mentioned in Tjalsma and Lohmann 
Figure 1. Location of Site 960 and depths of the nine analyzed samples.

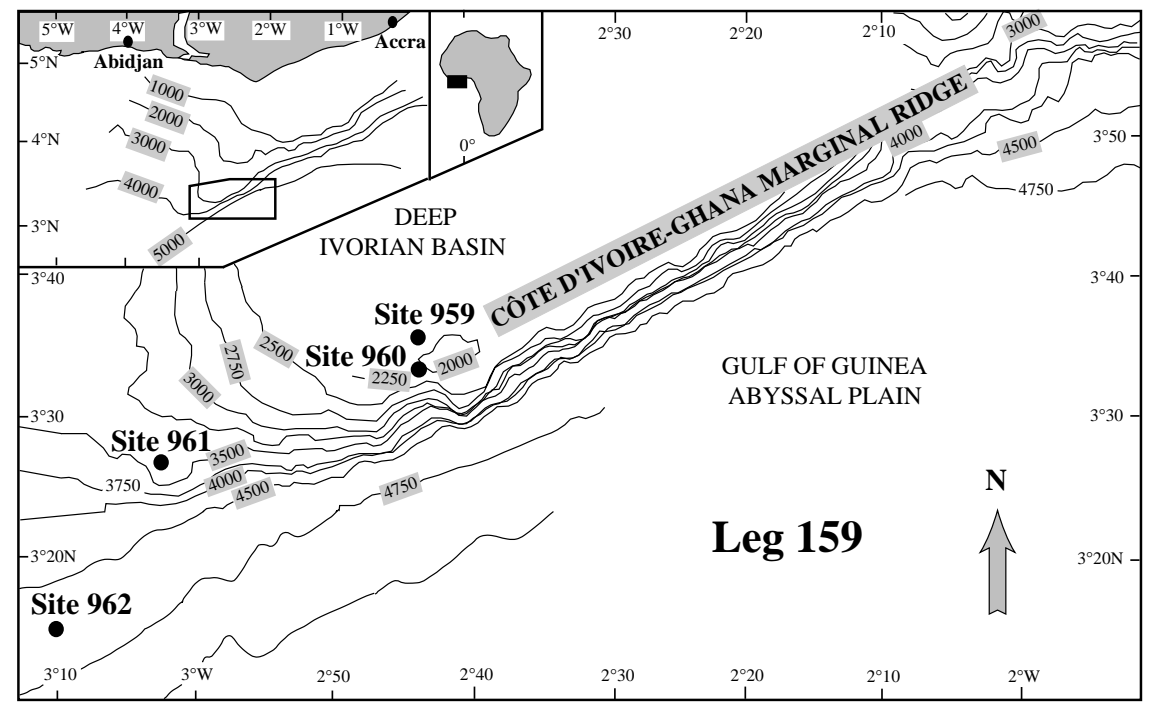

\begin{tabular}{|c|c|c|c|c|}
\hline $\begin{array}{c}\text { Hole } \\
\text { (coordinates) }\end{array}$ & Core, section & $\begin{array}{c}\text { Interval } \\
(\mathrm{cm})\end{array}$ & $\begin{array}{c}\text { Depth } \\
(\mathrm{mbsf})\end{array}$ & $\begin{array}{c}\text { Volume } \\
\left(\mathrm{cm}^{3}\right)\end{array}$ \\
\hline & & & & \\
\hline & & & & \\
\hline $960 \mathrm{~A}$ & $14 \mathrm{R}-1$ & $39-42$ & 117.29 & 20 \\
\hline & $15 \mathrm{R}-1$ & $71-74$ & 127.31 & 20 \\
\hline & $20 \mathrm{R}-1$ & $97-99$ & 175.47 & 10 \\
\hline $3^{\circ} 34.979 ' \mathrm{~N}$ & $21 \mathrm{R}-1$ & 1113 & 184.21 & 10 \\
\hline $2^{\circ} 44.009^{\prime} \mathrm{W}$ & & & & \\
\hline & & & & \\
\hline & $15 \mathrm{H}-1$ & $114-116$ & 130.84 & 10 \\
\hline $960 \mathrm{C}$ & $15 \mathrm{H}-3$ & $116-118$ & 133.86 & 10 \\
\hline & $15 \mathrm{H}-4$ & $113-115$ & 135.33 & 10 \\
\hline & $17 \mathrm{X}-1$ & $112-114$ & 141.32 & 10 \\
\hline $3^{\circ} 35.025^{\prime} \mathrm{N}$ & $22 \mathrm{X}-1$ & $66-68$ & 189.26 & 10 \\
\hline $2^{\circ} 43.990^{\prime} \mathrm{W}$ & \multicolumn{3}{|l}{} & \\
\hline
\end{tabular}

(1983) and in van Morkhoven et al. (1986), and found in the analyzed samples, are listed in Figure 4.

Two of the species found in Sample 159-960A-14R-1, 39-42 cm, are of special interest. According to previous authors, the FAD (First Appearance Datum) of Bulimina glomarchallengeri (Pl. 2, Fig. 1) is in Zone P14, as well as the last occurrence of Aragonia aragonensis (Pl. 4, Figs. 7, 8). Thus the co-occurrence of these two species leads to confer a P14 age to the assemblage (i.e., the upper part of the middle Eocene and, more precisely, the Bartonian standard stage; Odin and Luterbacher, 1992; Berggren et al., 1995). Although the planktonic species were not studied in detail, remains of Clavigerinella gr. eocanica (Pl. 4, Figs. 19, 20), which have been found with the benthic foraminifers, are in agreement with the age proposed here. This age is quite different from that initially suggested (pp. 178-182) in Shipboard Scientific Party (1996).

The assemblage found in Sample 159-960C-17X-1, 112-114 cm, is consistent with a similar stratigraphic assignment, but could also be slightly older (possibly P13 or even P12) because some markers, especially, Bulimina glomarchallengeri, are absent.

Because of the lack of calcareous microfossils, an exact biostratigraphic dating of the other samples analyzed is not possible.

\section{PALEOGEOGRAPHICAL DISTRIBUTION}

It is hard to recognize the global extension of benthic foraminifers. Detailed taxonomic investigations (including search of synonymies) are always needed since most of the time one can suspect that a different name is used for the same species on every continent.

Scarce species of the Eocene assemblage found in Holes 960A and 960C are nearly worldwide in their distribution. For example, Vaginulinopsis fragaria is recorded in the Tethyan realm, at least from Ukraine to Mexico and California, and also far away toward the north: Orphan Knoll (Berggren and Aubert, 1976) and northwestern European basins (England, Netherlands, northern Germany) up to paleolatitudes of $35^{\circ}-40^{\circ} \mathrm{N}$.

The greater part of the identified species is common in and characteristic of the Tethyan realm. Well known in the deep basins of the Caribbean area since the classic publications of Cole $(1927,1928)$, Nuttall (1930), Cushman (1939), Cushman and Stainforth (1945), Cushman and Renz (1946, 1948), and Beckmann (1953), they have also often been described in Alpine bathyal Eocene paleoenvironments by European micropaleontologists, such as Reuss (1851) and 


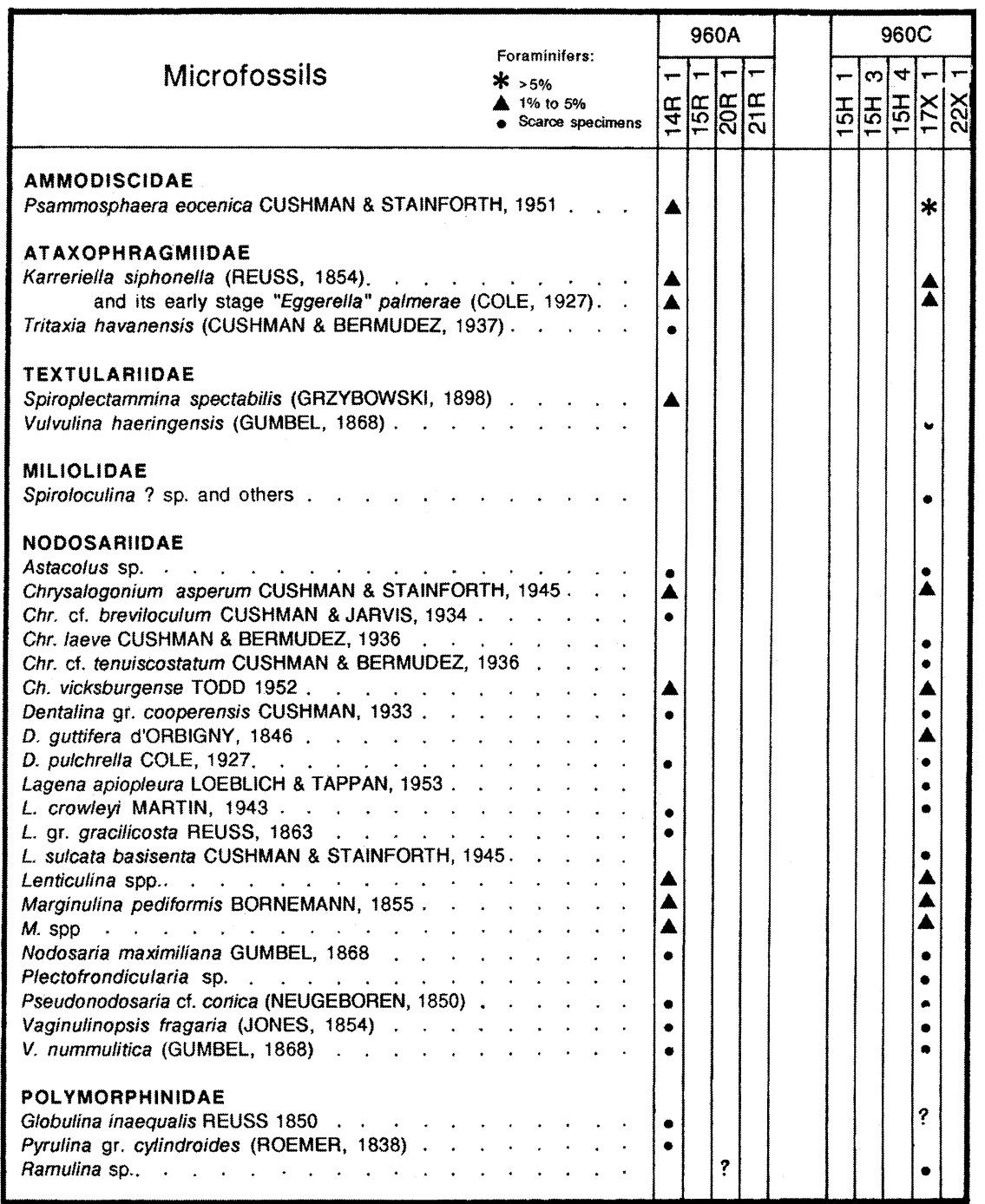

Figure 2. Distribution of microfossils in analyzed samples from Holes 960A and 960C
Gümbel (1868). According to Hagn (1956) and other more recent publications, several synonymies were established:

Cibicidoides eocaenus $($ Gümbel, 1868) $=$ C. tuxpamensis $($ Cole, $1928)=C$. perlucida $($ Nuttall, 1932);

Hanzawaia ammophila $($ Gümbel, 1868) $=$ H. cushmani $($ Nuttall, 1930); and

Osangularia pteromphalia $($ Gümbel, 1868) $=$ O. mexicana $($ Cole, 1928).

Some others are suspected and proposed here in the taxonomic notes. Thus, the Eocene central Atlantic assemblage is present in the Tethyan realm as well (Proto Decima and Bolli, 1978; Clark and Wright, 1984; Bolli et al., 1994).

\section{PALEOBATHYMETRY AND DISSOLUTION RATE}

The high foraminifer absolute abundance and species diversity in the fossiliferous samples indicate benthic environments (normal salinity, high concentrations of dissolved carbon dioxide and oxygen, and abundant food resources) of an open sea with water renewal.

With only $35 \%$ of planktonic foraminifers, following the diagram of van Marle et al. (1987), the assemblages found in Samples 159-
960A-14R-1, 39-42 cm, and 159-960C-17X-1, 112-114 cm, would be deposited no deeper than those in upper bathyal environments, with a water depth of 300-500 m or less. On the other hand, the benthic species that have been found in our samples are absent from the neritic and upper bathyal environments drilled by oil research companies in the neighboring Senegal, Ivory Coast, and Gabon margins (Brun, 1978). In addition, we observed in our samples a significant dissolution of foraminiferal tests, especially those of planktonic species. An indeterminate number of planktonic foraminifers probably disappeared. Thus, this assumption and direct observations do not allow us to take into account the planktonic/benthic ratio.

Publications of Tjalsma and Lohmann (1983) and van Morkhoven et al. (1986) about deep-water benthic foraminifers provide a list of some good paleobathymetric indices. According to the compilation shown in Figure 5, during middle Eocene times the seafloor on the top of the Ivorian Marginal Ridge was of a middle or lower bathyal type, at about $2 \pm 1 \mathrm{~km}$ water depth.

This assumption is consistent with the provisional conclusions about the geologic history of the Ivorian Marginal Ridge (Shipboard Scientific Party, 1996). An Early Cretaceous preliminary uplift was followed in the Late Cretaceous (Santonian? Campanian?) by a slow subsidence, bringing the actual seafloor toward a $2 \mathrm{~km}$ depth.

Boss and Wilkinson (1991) suggest that in the Atlantic Ocean, during middle Eocene times, the average Calcite Compensation 


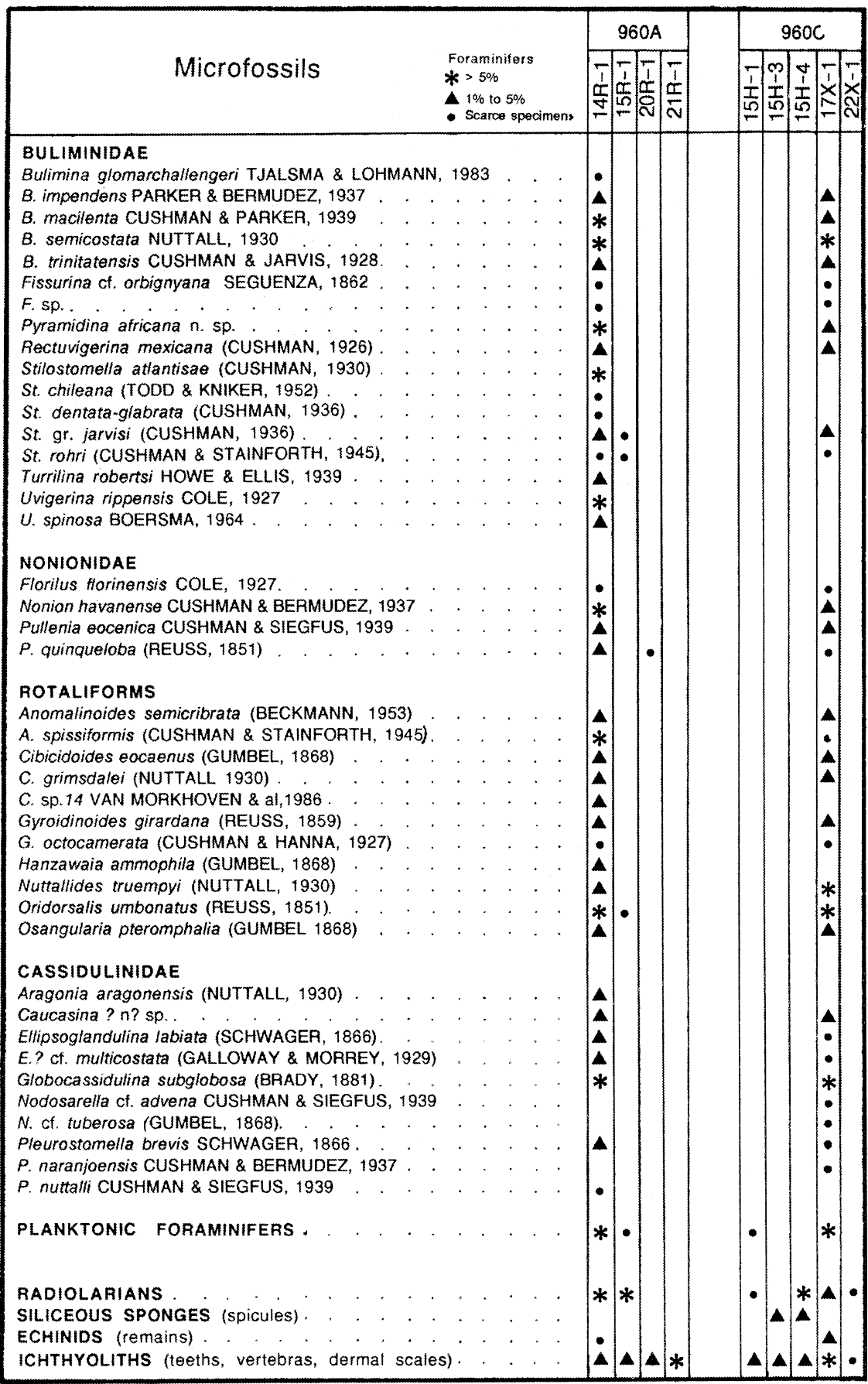

Figure 2 (continued).

In the Equatorial Atlantic Ocean area, the middle Eocene is known as a period of considerable instability (Oberhänsli et al., 1991). We interpret the sporadic levels with rich assemblages of foraminifers (and also of radiolarians) as short-term events of reduced oceanic productivity, probably initiated by fluctuations of equatorial upwellings.

\section{CONCLUSION}

Despite the importance of unrecovered intervals and of a limited sampling, the analysis of Eocene benthic foraminiferal assemblages from the marginal Ivorian Ridge permitted us to identify a long epi- 


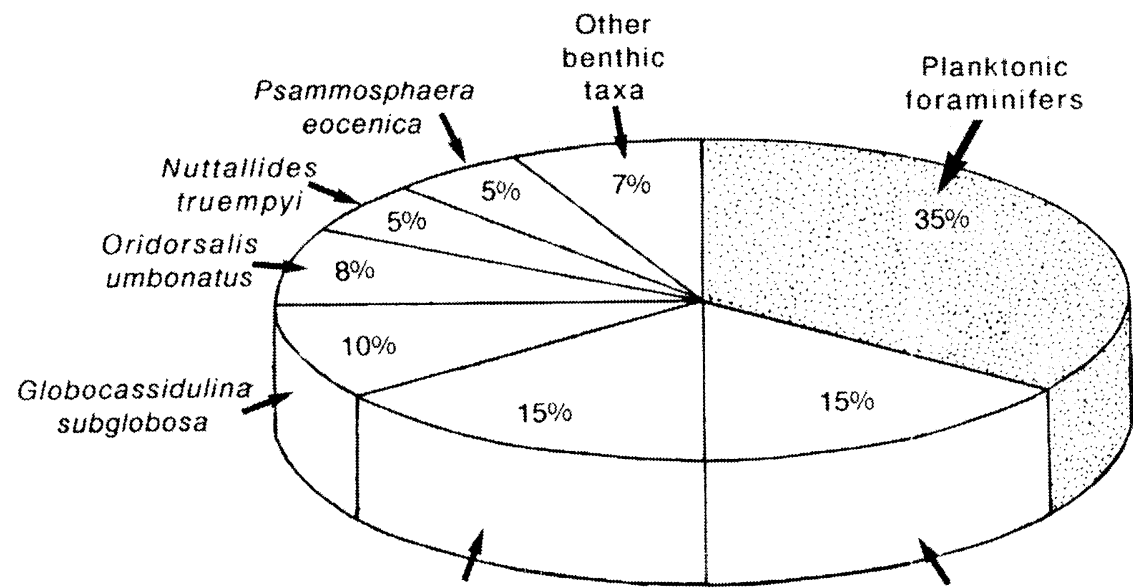

Genus Bulimina
Genus Stilostomella

Figure 3. Approximate percentage composition of the foraminiferal association in Sample 159-960C-17X-1, $112-114 \mathrm{~cm}$

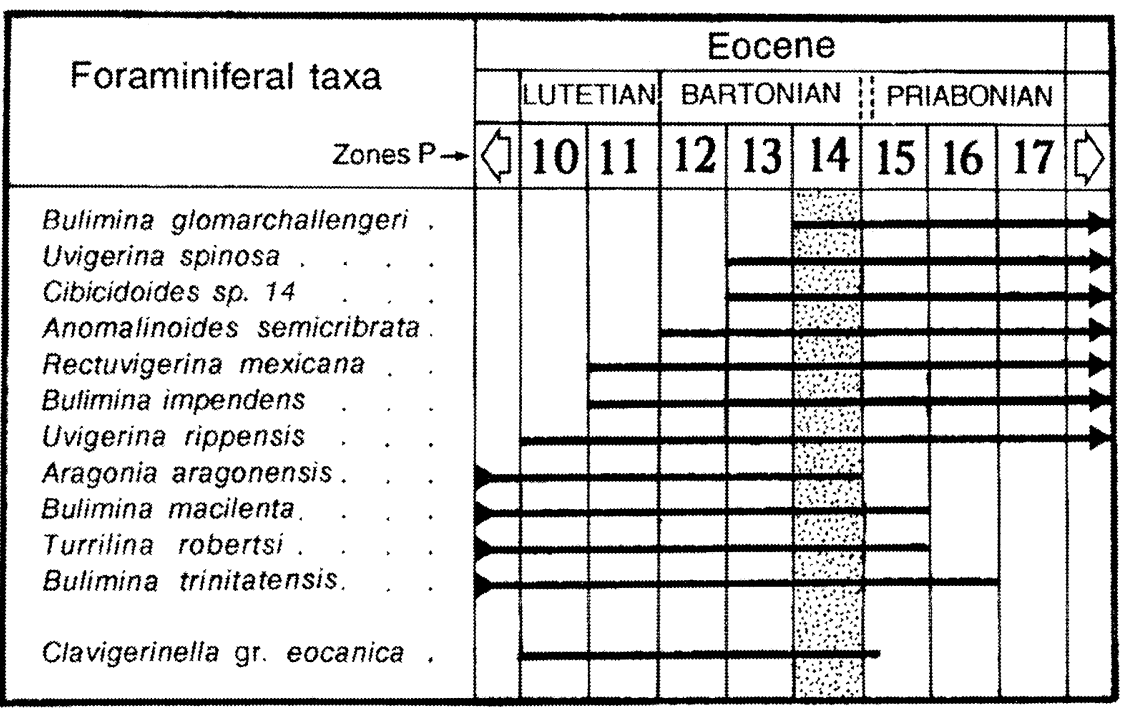

Figure 4. Stratigraphic range and correlation of some selected stratigraphic index foraminiferal species, chiefly according to Tjalsma and Lohmann (1983) and van Morkhoven et al. (1986). The joint occurrence of these species characterizes the P14 zone (stippled area). sode of strong carbonate dissolution. The depositional environment is estimated to be of a middle or lower bathyal type (i.e., $2 \pm 1 \mathrm{~km}$ water depth) close to that of the lower boundary of an oxygen minimum zone.

This long episode was interrupted during Bartonian times by one, or most probably, a few sporadic short event(s) of slighter dissolution, probably related to the fluctuations of the oceanic productivity, in relation to the regional pattern of upwellings.

\section{TAXONOMIC NOTES}

The benthic foraminiferal assemblage present in the middle Eocene samples of Holes 960A and 960C contains species that are already well known in the literature. Taxonomic references can be found in the Ellis and Messina Catalogue.

Thus, in the present paper, except the description of the new species, we have made only short taxonomic remarks about some species.

Karreriella siphonella (Reuss, 1851)

Plate 1, Figures 1-3

Gaudryina siphonella, Reuss, 1851, p. 78, pl. 5, figs. 40-42, (middle Oligocene from North Germany).

Aperture rounded or elliptical (not elongate) with a short tubular neck, situated toward the inner margin of the last formed chamber. "Eggerella" palm- erae Cole, 1927, from the Eocene of Trinidad, is regarded to be the early stage of $K$. siphonella. This species has not been reported earlier from deep-water deposits.

Vulvulina haeringensis (Gümbel, 1868)

Plate 1, Figures 5-7

Venilina haeringensis, Gümbel, 1868, p. 71, pl. 2, figs. 84 bis a \& b, ("Jüngste Nummulitenschichten" from Bavaria).

Vulvulina haeringensis (Gümbel, 1868) Hagn, 1956, p. 115, pl. 9, figs. 7-8.

Apex rounded. Sides nearly parallel. Sutures distinct, slightly raised and strongly curved backward.

It appeared difficult to distinguish $V$. haeringensis from the following:

Textilaria flabelliformis Gümbel, 1868 (Oligocene from Tirol);

Venilina nummulina Gümbel, 1868 (Oligocene from Tirol);

Vulvulina colei Cushman, 1932 (Eocene from Mexico); and

Vulvulina chirana Cushman and Stone, 1942 (late Eocene from Peru),

which are different by the more or less raised sutures and the number of uniserial chambers.

\section{Vaginulinopsis fragaria (Gümbel, 1868)}

Plate 1, Figure 8

Marginulina fragaria Gümbel, 1868, p. 57, pl. 1, fig. 58c (not 58a-b), (“Alteres Eocän Nummulitenmergel" from Bavaria). 
Figure 5. Paleobathymetric distribution of some selected benthic foraminifer taxa. Data are taken from numerous publications, including Boltovskoy and Wright (1976, p. 239), Resig (1976, p. 750), Tjalsma and Lohmann (1983), Boersma (1984), Van Morkhoven et al. (1986), and Murray (1991, p. 323).

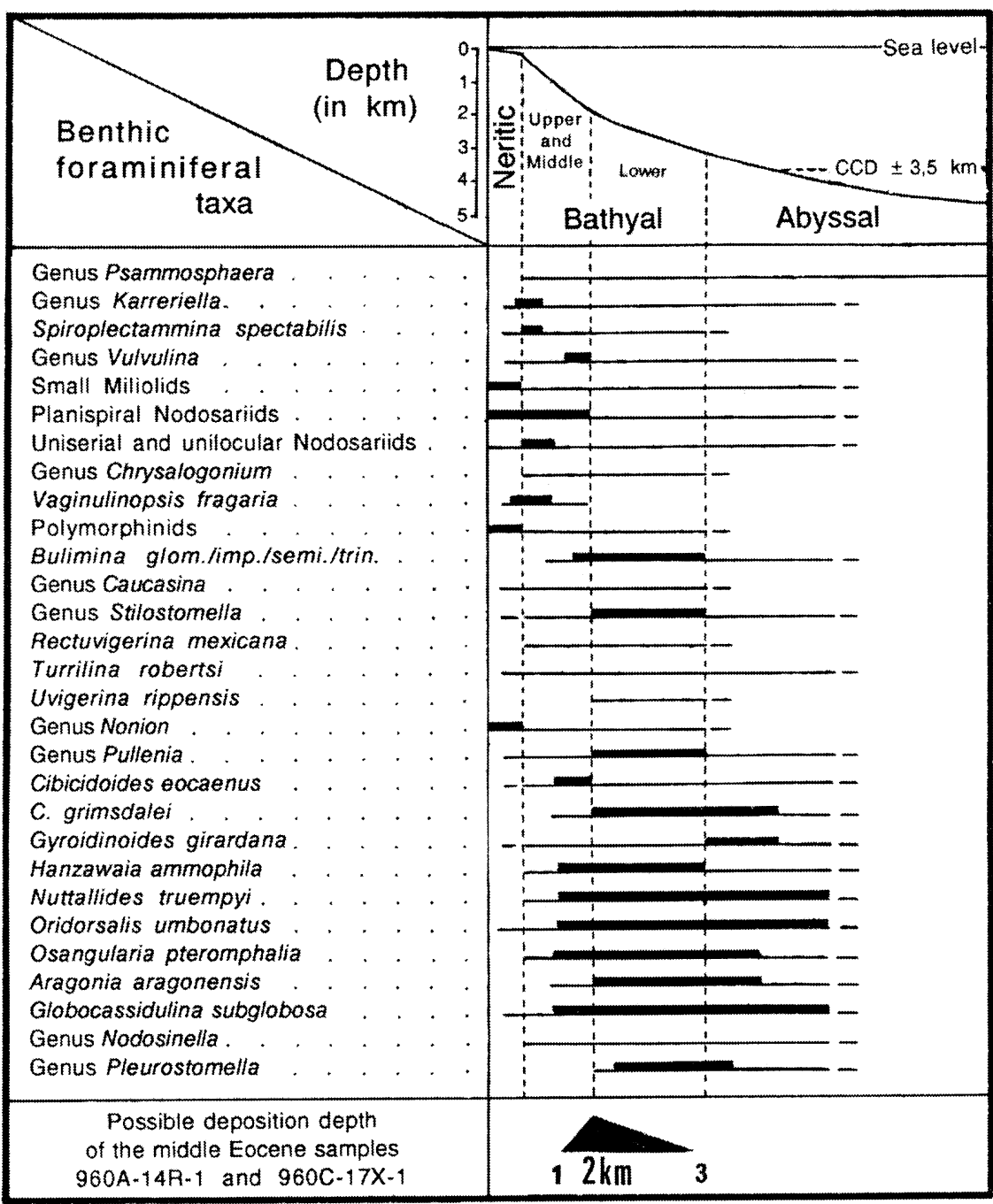

Dentalina guttifera d'Orbigny, 1846 Plate 1, Figure 4

The (more than $1.5 \mathrm{~mm}$ ). Ornamentation of rows of rounded tubercles best developed on the coiled portion of the test and giving place to elongate costae on later chambers or even to depressions in extreme maturity. According to the author's estimates of the type specimens, the next Paleocene-Eocene species

Cristellaria subaculeata tuberculata Plummer, 1926, (Paleocene of Texas); Cristellaria asperuliformis Nuttall, 1930, (early Eocene of Mexico);

Marginulina enbornensis Bowen, 1954, (Ypresian of London Basin); and Marginulinopsis wetherellii sensu Murray, Curry, Haynes and King 1989, p.

522, pl. 10.7, figs. 10-11, (not Marginulina wetherelli Jones, 1854),

(Ypresian from London basin)

seem similar to $V$. fragaria.

On other hand, this species appears to be related to, if not derived from, Cretaceous “Marginulina” decorata Reuss, 1855.

\section{Chrysalogonium vicksburgense Todd, 1952} Plate 1, Figure 9

Chrysalogonium vicksburgense Todd, 1952, p. 13, pl. 2, figs. 13-15, (Oligocene from Mississippi).

This species has been generally and erroneously cited under the name Nodosaria longiscata (not d'Orbigny, 1846). Ch. vicksburgense appears to be related with the Paleocene Ch. arkansasanum Cushman and Todd, 1946.
Dentalina guttifera d'Orbigny, 1846, p. 49, pl. 2, figs. 11-13, (Miocene from Vienna basin).

Nodosaria guttifera (d'Orbigny, 1846), Papp and Schmid, 1985, p. 30, pl. 13, figs. 1-6.

Dentalina soluta Reuss, 1851, from the Eocene of North Germany (see Kiesel, 1970, p. 226, pl. 8; fig. 4) is a synonym.

\section{Lagena crowlei Martin, 1943}

Plate 1, Figure 15

Lagena crowlei Martin, 1943, p., 108, pl. 5, figs. 5a-b, (Lodo formation California).

Test ornamented with nine longitudinal rows of 15 hollow cone-shaped tubules.

Lagena ciperensis Cushman and Stainforth, 1945, from the Oligocene Cipero formation from Trinidad is a synonym.

\section{Pyramidina africana $\mathrm{n} . \mathrm{sp}$ Plate 3, Figures 1-11}

Holotype: Plate 3, Figures 1-2.

Paratypes: Plate 3, Figures 3-11. 
Depository: The holotype and two paratypes in the Museum National d'Histoire Naturelle de Paris. The other paratypes are in the author's collection.

Type locality: Marginal Ivorian Ridge, central Atlantic Ocean: $3^{\circ} 34.979^{\prime} \mathrm{N}$ and $2^{\circ} 44.009^{\prime} \mathrm{W}$

Type sample: Section 159-960A-14R-1, 39-42 cm; Depth: 117.29 meters below seafloor (mbsf).

Type stratum: Upper part of middle Eocene (Bartonian), zone P14.

Diagnostic features: Test fusiform, broadest at the middle. Transverse section rounded and not carinated. Chambers broad, triserially and closely arranged. Sutures distinct and depressed. Wall smooth except at the basal part of chambers occupied by dense, cylindrical hollow pustulas. Aperture oval in outline, subterminal, bordered by a small collar, with more or less defined suture connecting aperture to the base of chamber.

Holotype: length: $0.275 \mathrm{~mm}$; diameter: $0.150 \mathrm{~mm}$

Paratypes: length: 0.225 to $0.300 \mathrm{~mm}$; diameter: 0.125 to $0.150 \mathrm{~mm}$.

Affinities: By its transverse section outline and its apertural features the new species is intermediate between two genera: Uvigerinella Cushman, 1926, and Pyramidina. Brotzen, 1948. But, like the type-species of the last genus, $P$. africana had a test closely triserial without tendency to become biserial.

The new species is related to the Paleocene species $P$. curvisuturata (Brotzen, 1940) $=P$. crassa Brotzen, 1948, but it is different by its rounded transverse section, the pustulated wall and its apertural collar. Paleocene $P$. europaea (Cushman and Edwards, 1937) and Eocene Angulogerina muralis (Terquem, 1882) = A. mauricensis Howe, 1939 have chambers subtriangular in section with a pustulated wall and characteristic re-entrants of the basal suture.

Caucasina? n? sp.

Plate 4, Figures 12-16

Specimens in bad state of preservation with a dense coating of small calcite overgrowths upon the test surface (Pl. 4, Fig. 14). These specimens show an aperture, an elongate-oval, high loop at the inner margin of the last chamber at right angle to suture; sutures slightly depressed with some small (arched?) sutural openings; wall coarsely perforate.

They are tentatively regarded to belong to the genus Caucasina Khalilov, 1951 (Loeblich and Tappan, 1964)

\section{ACKNOWLEDGMENTS}

The author is very grateful to Ivan de Klasz, Kunio Kaiho, Michel Moullade, and Pierre Saint-Marc for the critical review of the manuscript and Rose Sauser for her comments on the language and presentation aspect.

\section{REFERENCES}

Beckmann, J.P., 1953. Die Foraminiferen der Oceanic Formation (EocaenOligocenaen) von Barbadoes. Eclogae Geol. Helv., 46:301-412.

Berggren, W.A., and Aubert, J., 1976. Eocene benthonic foraminiferal biostratigraphy and paleobathymetry of Orphan Knoll (Labrador Sea). Micropaleontology, 22:327-346.

Berggren, W.A., Kent, D.V., Swisher, C.C., III, and Aubry, M.-P., 1995. A revised Cenozoic geochronology and chronostratigraphy. In Berggren, W.A., Kent, D.V., Aubry, M.-P., and Hardenbol, J. (Eds.), Geochronology, Time Scales and Global Stratigraphic Correlation. Spec. Publ.Soc. Econ. Paleontol. Mineral., 54:129-212.

Boersma, A., 1984. A Handbook of Common Tertiary Uvigerina: Stony Point, NY (Microclimates Press).

Bolli, H.M., Beckmann, J.-P., and Saunders, J.B., 1994. Benthic Foraminiferal Biostratigraphy of the South Caribbean Region: Cambridge (Cambridge Univ. Press).

Boltovskoy, E., and Wright, R., 1976. Recent Foraminifera: The Hague (W. Junk).
Boss, S.K., and Wilkinson, B.H., 1991. Planktogenic/eustatic control on cratonic/oceanic carbonate accumulation. J. Geol., 99:497-513.

Brun, M., 1978. Microfossiles de Côte d'Ivoire. Le Paléogène et la limite Crétacé/Tertiaire. Apport de l'exoscopie à la connaissance des paléoenvironnements [Thèse doctorat]. Univ. Provence, Marseille.

Clark, M.W., and Wright, R.C., 1984. Paleogene abyssal foraminifers from the Cape and Angola basins, South Atlantic Ocean: DSDP 73. In Hsü, K.J., LaBrecque, J.L., et al., Init. Repts. DSDP, 73: Washington (U.S. Govt. Printing Office), 459-480.

Cole, W.S., 1927. A foraminiferal fauna from the Guayabal Formation in Mexico. Bull. Am. Paleontol., 14:1-46.

1928. A foraminiferal fauna from the Chapapote Formation in Mexico. Bull. Am. Paleontol., 14:1-32.

Cushman, J.A., 1939. Eocene Foraminifera from submarine cores off the eastern coast of North America. Contr. Cushman Lab. Foraminiferal Res., 15:49-76.

Cushman, J.A., and Renz, H.H., 1946. The foraminiferal fauna of the Lizard Springs Formation of Trinidad, British West Indies. Spec. Publ. Cushman Lab. Foraminiferal Res., 18:1-48.

1948. Eocene Foraminifera of the Navet and Hospital Hill Formations of Trinidad, B.W.I. Spec. Publ. Cushman Lab. Foraminiferal Res., $24: 1-42$.

Cushman, J.A., and Stainforth, R.M., 1945. The foraminifera of the Cipero Marl Formation of Trinidad, British West Indies. Spec. Publ. Cushman Lab. Foraminiferal Res., 14:1-75.

d'Orbigny, A., 1846. Foraminifères Fossiles du Bassin Tertiaire de Vienne (Autriche): Paris (Gide).

Ellis, B.F., and Messina, A., 1940. Catalogue of Foraminifera. Spec. Publ., Am. Mus. Nat. Hist.

Gümbel, C.W., 1868. Beiträge zur Foraminiferenfauna der nordalpinen, älteren Eocängeblide oder der Kressenberger Nummulitenschichten. Bayerische Akad. Wiss. Abh., Math.-Physik. Kl., 10:579-730.

Hagn, H., 1956. Geologische und paläontologische Untersuchungen im Tertiär des Monte Brione und seiner Umgebung. Palaeontology, 107:67210 .

Ingle, J.C., 1980. Cenozoic paleobathymetry and depositional history of selected sequences within the Southern California continental borderland. Spec. Publ. Cushman Found. Foraminiferal Res., 19:163-195.

Kiesel, Y., 1970. Die Foraminiferenfauna der paläozänen und eozänen Schichtenfolge der Deutschen Demokratischen Republik. Palaeontologica A, 4:163-394.

Loeblich, A.R., and Tappan, H., 1964. The species and stratigraphic Distribution of Caucasina and Aelomorphella, new genus (Foraminiferida). Tulane Stud. Geol., 2:69-88.

Martin, L.T., 1943. Eocene foraminifera from the type Lodo formation, Fresno County, California. Stanford Univ. Publ. Geol. Sci., 3:1-35.

Murray, J.W., 1991. Ecology and Palaeoecology of Benthic Foraminifera: London (Longman).

Murray, J.W., Curry, D., Haynes, J.R., and King, C., 1989. Palaeogene. In Jenkins, D.G., and Murray, J.W. (Eds.), Stratigraphical Atlas of Fossil Foraminifera (2nd ed.). Br. Micropaleontol. Soc. Ser., 490-536.

Nuttall, W.L.F., 1930. Eocene Foraminifera from Mexico. J. Paleontol., $4: 271-293$

Oberhänsli, H., Muller-Merz, E., and Oberhänsli, R., 1991. Eocene paleoceanographic evolution at $2-3^{\circ} \mathrm{S}$ in the Atlantic Ocean. Palaeogeogr. Palaeoclimatol., Palaeoecol., 83:173-215.

Odin, G.S., and Luterbacher, H.P., 1992. The age of the Paleogene Stage Boundaries. Neues. Jahrb. Geol. Palaeontol. Abh., 186:21-48.

Papp, A., and Schmid, M.E., 1985. Die fossilen Foraminiferen des tertiären Beckens von Wien. Abh. Geol. Bundesanst. (Austria), 37:7-311.

Proto Decima, F., and Bolli, H.M., 1978. Southeast Atlantic DSDP Leg 40 Paleogene benthic Foraminifers. In Bolli, H.M., Ryan, W.B.F., et. al, Init. Repts. DSDP, 40: Washington (U.S. Govt. Printing Office), 783-809.

Resig, J.M., 1976. Benthic foraminiferal stratigraphy, eastern margin, Nazca Plate. In Yeats, R.S., Hart, S.R., et al., Init. Repts. DSDP, 34: (Washington U.S. Govt. Printing Office), 743-759.

Reuss, A.E., 1851. Uber die fossilen Foraminiferen und Entomostracean der Septarienthone der umgegend von Berlin. Z. Dtsch. Geol. Ges., 3:49-92.

Shipboard Scientific Party, 1996. Site 960. In Mascle, J., Lohmann, G.P., Clift, P.D. et al, Proc ODP, Init. Repts, 159: College Station, TX (Ocean Drilling Program), 151-215. 
Tjalsma, R.C., and Lohmann, G.P., 1983. Paleocene-Eocene bathyal and abyssal benthic foraminifera from the Atlantic Ocean. Micropaleontol. Spec. Publ., 4.

Todd, R., 1952. Vicksburg (Oligocene) smaller foraminifera from Mississippi. Geol. Surv. Prof. Pap. U.S., 214:1-49.

van Marle, L.J., Van Hinte, J.E., and Nederbragt, A.J., 1987. Plankton percentage of the foraminiferal fauna in seafloor samples from the Australian-Irian Jaya continental margin, Eastern Indonesia. Mar. Geol., $77: 151-156$. van Morkhoven, F.P.C.M., Berggren, W.A., and Edwards, A.S., 1986. Cenozoic cosmopolitan deep-water benthic foraminifera. Bull. Cent. Rech. Explor-Prod. Elf-Aquitaine, Mem. 11.

Date of initial receipt: 8 July 1996

Date of acceptance: 28 February 1997

Ms 159SR-017 


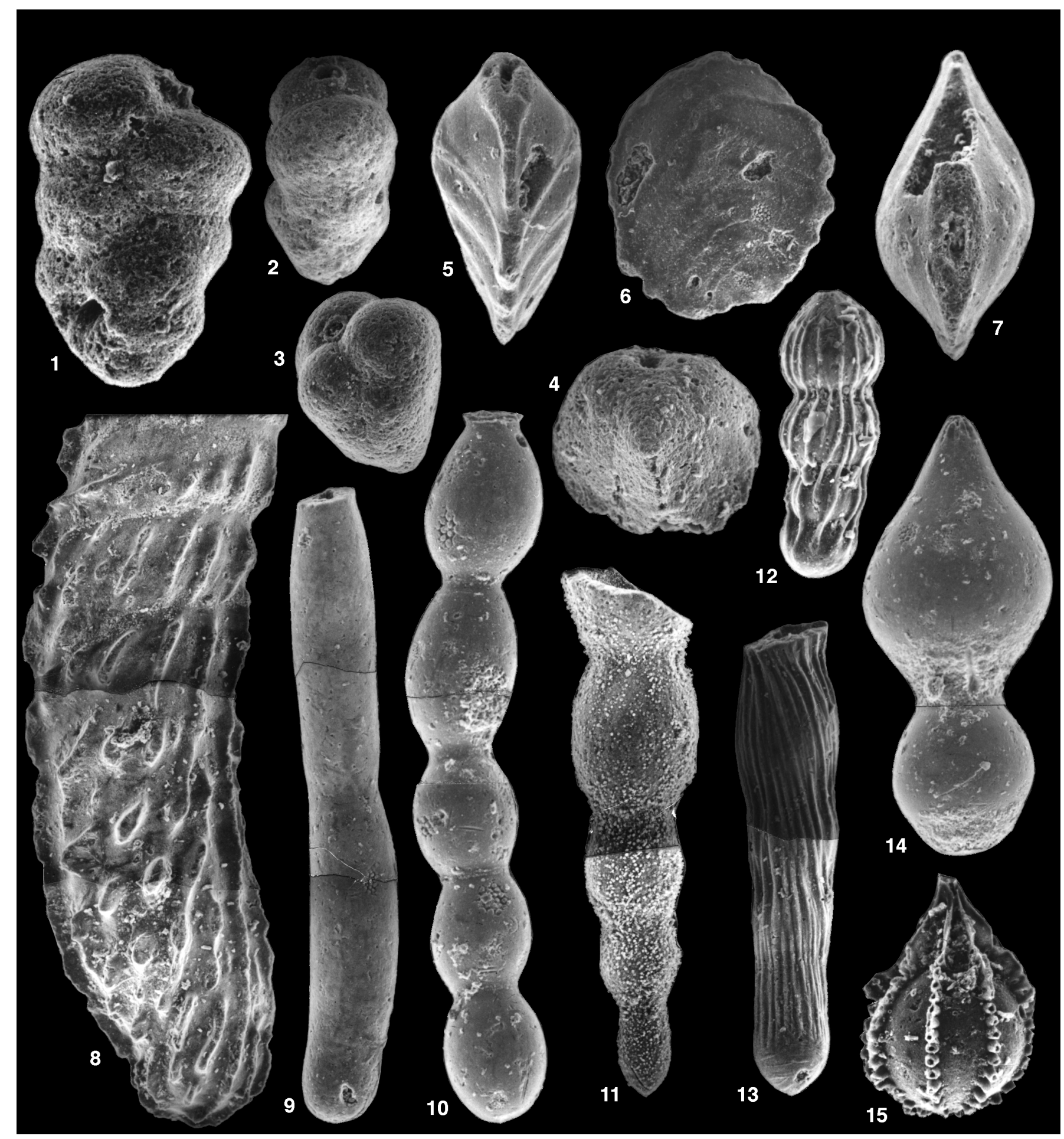

Plate 1. 1, 2. Karreriella siphonella; Sample 159-960A-14R-1, 39-42 cm. 1: 120×. 2: 80×. 3. "Eggerella" palmerae; Sample 159-960C-17X-1, 112-114 cm, 100×. 4. Tritaxia havanensis; Sample 159-960A-14R-1, 39-42 cm, 80×. 5-7: Vulvulina haeringensis; Sample 159-960C-17X-1, 112-114 cm. 5: oblique view, 65×. 6: 50×. 7: apertural view: 80×. 8. Vaginulinopsis fragaria; Sample 159-960A-14R-1, 39-42 cm, 50×. 9. Chrysalogonium vicksburgense; Sample 159960A-14R-1, 39-42 cm, 60×. 10. Chrysalogonium laeve; Sample 159-960C-17X-1, 112-114 cm, 60×. 11. Chrysalogonium asperum; Sample 159-960A-14R1, 39-42 cm, 60×. 12. Chrysalogonium cf. breviloculum; Sample 159-960A-14R-1, 39-42 cm, 60×. 13. Chrysalogonium cf. tenuiscostatum; Sample 159960A-14R-1, 39-42 cm, 105×. 14. Dentalina guttifera; Sample 159-960A-14R-1, 39-42 cm, 50×. 15. Lagena crowleii; Sample 159-960A-14R-1, 39-42 cm, $130 \times$. 


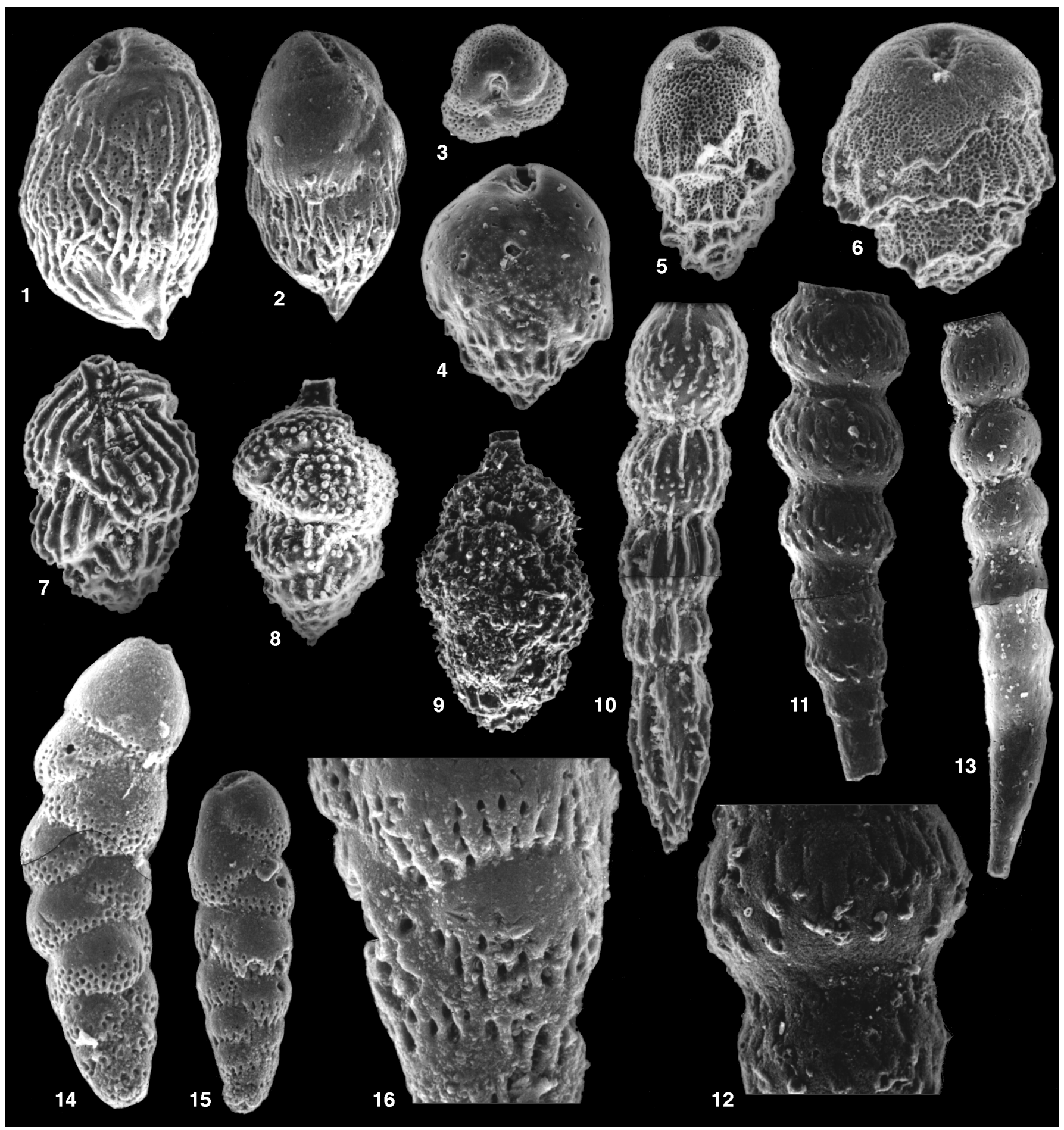

Plate 2. 1. Bulimina glomarchallengeri; Sample 159-960A-14R-1, 39-42 cm, 170×. 2, 3. Bulimina semicostata; 2: Sample 159-960C-17X-1, 112-114 cm, 75×. 3: Sample 159-960A-14R-1, 39-42 cm, 80×. 4. Bulimina macilenta; Sample 159-960A-14R-1, 39-42 cm, 100×. 5. Bulimina trinidadensis; Sample 159-960A14R-1, 39-42 cm, 125×. 6. Bulimina impendens; Sample 159-960C-17X-1, 112-114 cm, 110×. 7, 8. Uvigerina rippensis; Sample 159-960A-14R-1, 39-42 cm. 7: 100×. 8: 75×. 9. Uvigerina spinosa; Sample 159-960A-14R-1, 39-42 cm, 100×. 10. Stilostomella chileana; Sample 159-960A-14R-1, 39-42 cm, 100×. 1113. Stilostomella gr. jarvisi; Sample 159-960A-14R-1, 39-42 cm. 11: $75 \times .12$ : etched surface test, details of figure: $160 \times$. 13: $50 \times$. 14-16. Rectuvigerina mexicana; Sample 159-960C-17R-1, 112-114 cm. 14: 160×. 15: 120×. 16: etched surface test: 370×. 


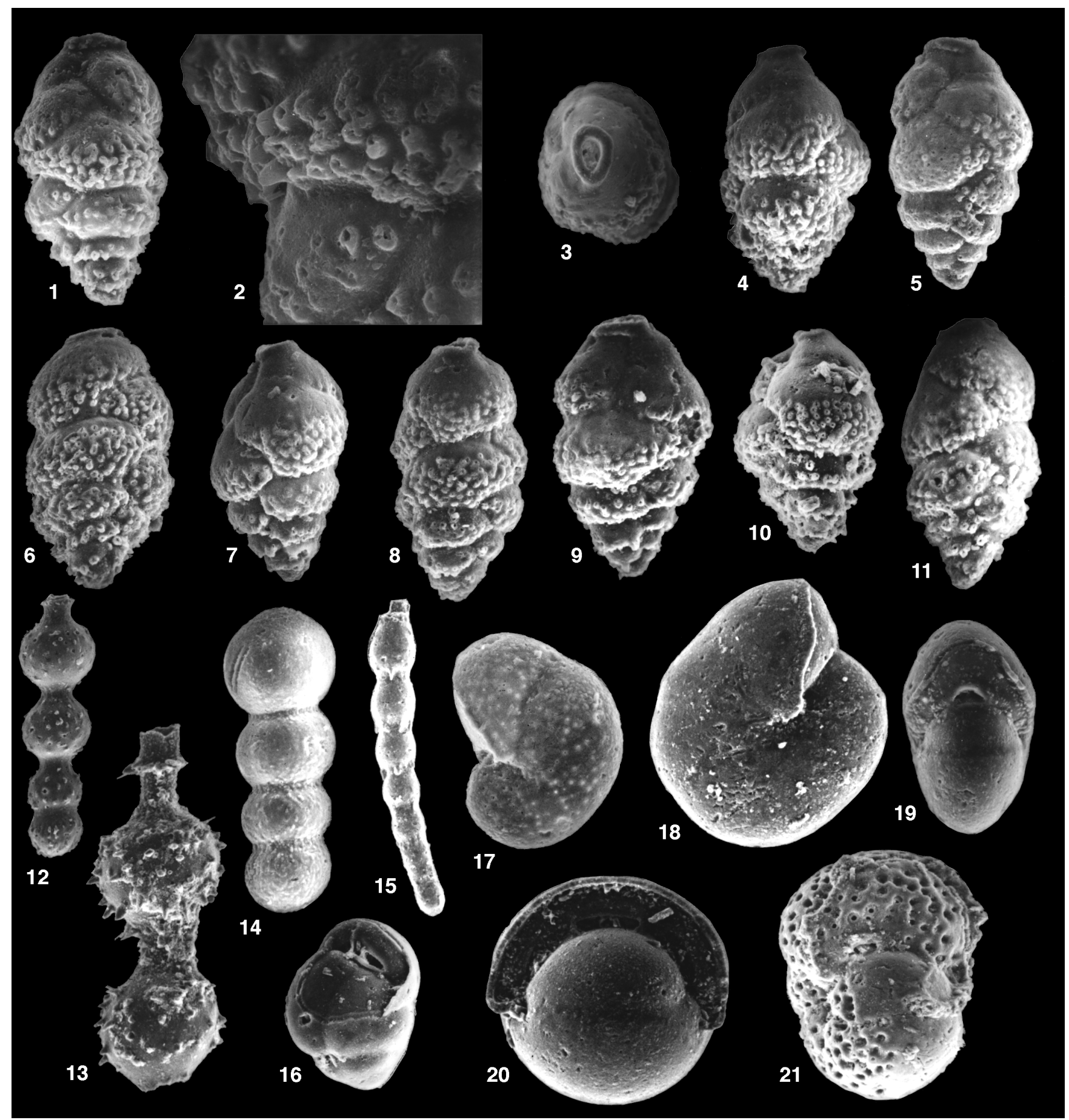

Plate 3. 1-11. Pyramidina africana $\mathrm{n}$. sp.; Sample 159-960A-14R-1, 39-42 cm. 1: holotype: 160×. 2: cylindrical hollow pustules of surface test, details of Figure 1, 500×. 3-11: paratypes, 160×. 12, 13. Stilostomella atlantisae; 12: Sample 159-960A-14R-1, 39-42 cm, etched specimen, 55×. 13: Sample 159-960C17X-1, 112-114 cm, well-preserved specimen, 150×. 14. Stilostomella rohri.; Sample 159-960C-17X-1, 112-114 cm, 100×. 15. Stilostomella dentata-glabrata; Sample 159-960A-14R-1, 39-42 cm, 80×. 16. Turrilina robertsi; Sample 159-960A-14R-1, 39-42 cm, 80×. 17. Florilus florinensis; Sample 159-960A14R-1, 39-42 cm, 150×. 18, 19. Nonion havanense; Sample 159-960A-14R-1, 39-42 cm, 18: lateral view, 120×. 19: edge view, 100×. 20. Pullenia eocenica; Sample 159-960A-14R-1, 39-42 cm, edge view, 110×. 21. Anomalinoides semicribrata; Sample 159-960A-14R-1, 39-42 cm, edge view, 100×. 


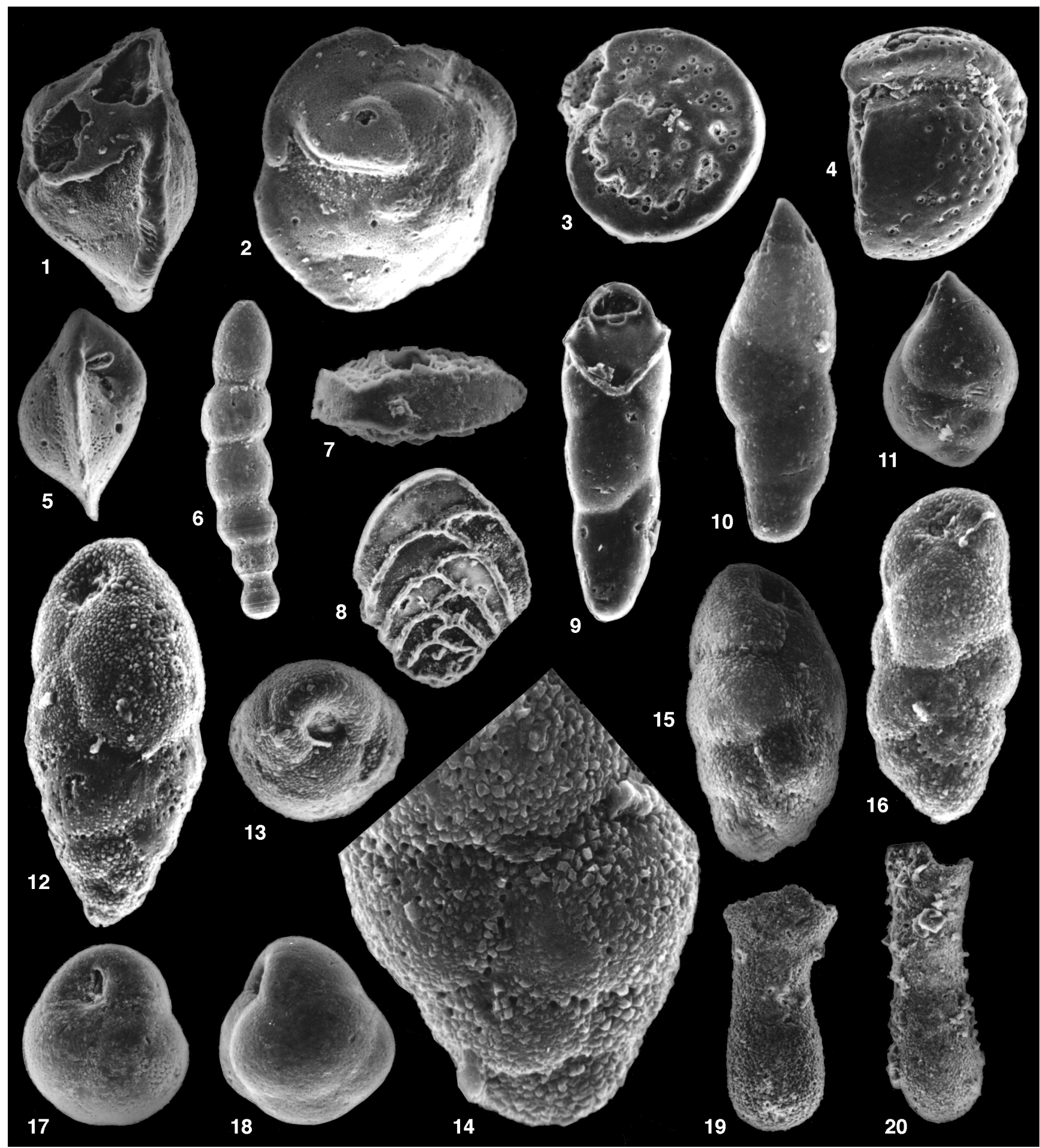

Plate 4. 1, 2. Nuttallides truempyii; Sample 159-960C-17X-1, 112-114 cm. 1: edge view, 70×. 2: umbilical view, 75×. 3, 4. Cibicidoides grimsdalei; Sample 159-960A-14R-1, 39-42 cm, 3: spiral view, 80×. 4: edge view, 100×. 5. Osangularia pteromphalia; Sample 159-960A-14R-1, 39-42 cm, edge view, $80 \times$. 6. Nodosarella cf. advena; Sample 159-960C-17X-1, 112-114 cm, 65×. 7, 8. Aragonia aragonensis; Sample 159-960A-14R-1, 39-42 cm. 7: edge view, 100×. 8: lateral view, 100×. 9. Pleurostomella nuttalli; Sample 159-960A-14R-1, 39-42 cm, 180×. 10. Pleurostomella naranjoensis; Sample 159960C-17X-1, 112-114 cm, 180×. 11. Pleurostomella brevis; Sample 159-960A-4R-1, 39-42 cm, 70×. 12-16. Caucasina ? n? sp.; Sample 159-960A14R-1, 29-42 cm. 12: 250×. 13: apertural view, 250×. 14: details of coated test surface, 600×; 15: 250×. 17, 18. Globocassidulina subglobosa; Sample 159-960C-17X-1, 112-114 cm, 100×. 19, 20. Clavigerinella gr. eocanica; Sample 159-960A-14R-1, 39-42 cm, isolated chambers, 100×. 